Int. J. Dev. Biol. 53: 517-524 (2009)

doi: $10.1387 / \mathrm{ijdb} .082651 \mathrm{dv}$

\title{
A critical role for myoglobin in zebrafish development
}

\author{
DANIELLE H. VLECKEN ${ }^{1}$, JANWILLEM TESTERINK ${ }^{3}$, ELISABETH B. OTT ${ }^{2}$, PHILIPPE A. SAKALIS ${ }^{2}$ \\ RICHARD T. JASPERS ${ }^{3}$ and CHRISTOPH P. BAGOWSKI*,1,2
}

\begin{abstract}
Institute of Biology, ${ }^{1}$ Department of Integrative Zoology and ${ }^{2}$ Department of Molecular and Cellular Biology, University of Leiden, The Netherlands and ${ }^{3}$ Research Institute MOVE, Faculty of Human Movement Sciences, VU University Amsterdam, The Netherlands
\end{abstract}

\begin{abstract}
The globin family, including hemoglobin, myoglobin, neuroglobin and cytoglobin, plays an important role in oxygen storage and delivery. Myoglobin has been shown to be necessary for cardiac function during development, but no information is currently available on the developmental regulation of myoglobin gene expression during embryogenesis. In this study, we used whole mount in situ hybridization to visualize myoglobin mRNA expression during zebrafish development. Our results show for the first time the spatial and temporal gene expression pattern of myoglobin during embryogenesis. Myoglobin was expressed as a maternal RNA and ubiquitous expression was observed until the end of gastrulation. At later stages of development, we discovered novel expression domains for myoglobin, including several nonmuscular ones. Environmental stresses, like low oxygen tension (hypoxia) can lead to a developmental delay in zebrafish embryos. We show here that hypoxic stress induces myoglobin expression in skeletal muscle cells of anterior somites and in the dorsal aorta of zebrafish larvae. Finally, we analyzed the role of myoglobins in development by targeted gene knock-down. Silencing myoglobin in zebrafish embryos with gene-specific morpholinos led to a dose dependent curvature, vascular defects, enlarged pericardia and reduction of the gut. In conclusion, our results indicate that myoglobin plays a crucial role in zebrafish development and is important for angiogenesis and gut development.
\end{abstract}

KEY WORDS: development, zebrafish, hypoxia, heart development, vascularization, angiogenesis

\section{Introduction}

The globin family in vertebrates consists of four types of globins, hemoglobin, myoglobin (Mb), neuroglobin and cytoglobin which differ in structure, tissue distribution and function (Pesce et al., 2002). Globins are small respiratory proteins that reversibly bind $\mathrm{O}_{2}$ by means of an iron-containing porphyrin ring. They are widely distributed through all three kingdoms of life and can be found from bacteria to eukaryotes (Vinogradov et al., 2006).

$\mathrm{Mb}$ contributes to intracellular oxygen storage and facilitates transcellular diffusion of oxygen (Flogel et al., 2004, Ordway and Garry, 2004, Suzuki and Imai, 1998, Takahashi and Doi, 1998, Wittenberg and Wittenberg, 2003).

The importance of $\mathrm{Mb}$ for mammalian development has been demonstrated by studies of $\mathrm{Mb}$ deficient mice. Initially it was shown that mice without myoglobin, are fertile and exhibit normal exercise capacity and a normal ventilatory response to low oxygen levels (hypoxia) (Garry et al., 1998). A later study, however showed that the majority of myoglobin deficient mice die in utero at midgestation with signs of cardiac failure (Meeson et al., 2001). It was shown that $M b$ is necessary for cardiac function during development. However, some animals showed adaptive responses which could fully compensate for the defect in cellular oxygen transport (Godecke et al., 1999, Meeson et al., 2001).

In adult animals, $\mathrm{Mb}$ is typically expressed in skeletal and cardiac muscle tissues, where continuous oxygen flow is required for high activity of aerobic metabolism (Iwanami et al., 2006, Leede Groot et al., 1998). Mb expression studies were mainly focused on cardiac and skeletal muscle tissue. Recent microarray studies have shown that $\mathrm{Mb}$ is also expressed in a range of other tissues, e.g. in the gills of adult zebrafish (van der Meer et al., 2005) as well as in the liver, gills and brain of adult carp (Fraser et al., 2006).

Still little is known about the expression pattern of $\mathrm{Mb}$ during vertebrate development. Longo et al. (1973) investigated Mb

Abbreviations used in this paper: dpf, days post fertilization; Mb, myoglobin; MBT, mid-blastula transition; MO, morpholino.

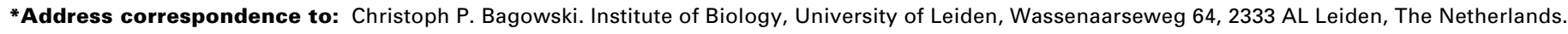
Tel: +31-(0)71-527-4802. Fax: +31-(0)71-527-4999. e-mail: bagowski@rulbim.leidenuniv.nl
} 
expression in embryonic tissue samples of human and sheep cardiac and skeletal muscle and found that $\mathrm{Mb}$ protein accumulates in cardiac muscle early in fetal development. However, Mb protein expression did not appear in skeletal muscle until late in gestation. Weller et al. also investigated embryonic tissue samples from mouse and human cardiac and skeletal muscles and found that Mb was expressed in embryonic mouse cardiac and skeletal muscle after 14 days of gestation and at 10 weeks of gestation in human skeletal muscle (Weller et al., 1986).

We describe here the temporal and spatial gene expression patterns of $\mathrm{Mb}$ during zebrafish development and identify novel expression domains of this important member of the globin family. We further show that Mb knock down leads to severe defects in developing embryos and that hypoxic stress induces Mb expression.

\section{Results}

\section{Genomic organization of zebrafish myoglobin and phyloge- netic analysis of myoglobins}

The zebrafish Mb gene had been initially described by Madden et al. (Madden et al., 2004). We have cloned here a zebrafish Mb cDNA in order to study its expression pattern during embryogenesis. The derived amino acid (Aa) sequence was identical to a previously described zebrafish Mb clone (GenBank Acc. Number:

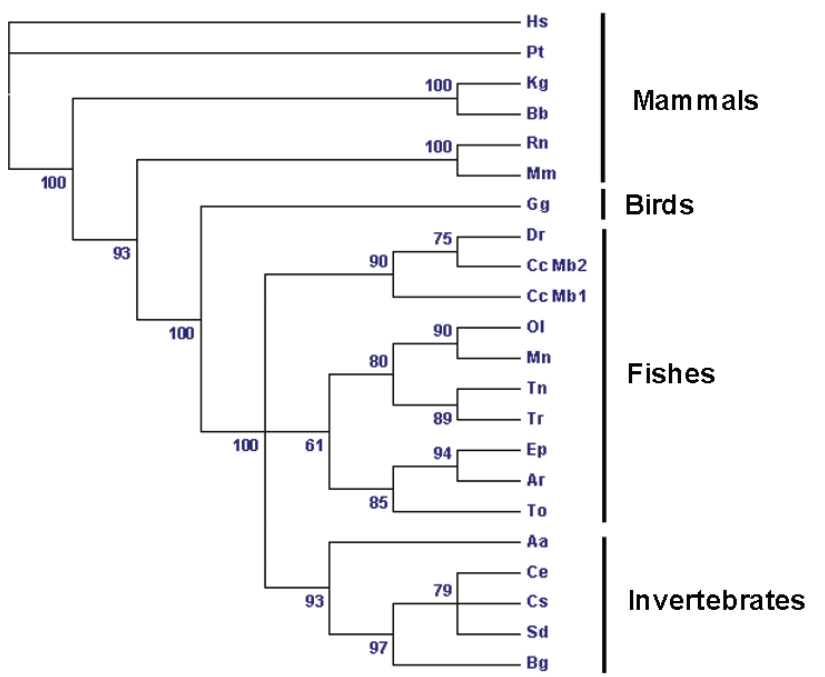

Fig. 1. Phylogenetic analysis of myoglobins (Mbs). Shown is the phylogenetic analysis of Mbs based on aminoacid sequences of 16 different vertebrate and 5 invertebrate species. Abbreviations used and accession numbers (GenBank and Ensembl): Hs: Homo Sapiens (Human) (CU013116); Pt:Pan troglodytes (Chimpanzee) (ENSPTRG00000023553); Kg: Kogia breviceps (Pygmy Sperm whale) (AB271147); Bb: Balaenoptera borealis (Sei whale) (AB271151); Rn: Rattus norwegicus (Rat) (NM_021588); Mm: Mus musculus (Mouse) (NM_013593); Gg: Gallus gallus (Chicken) (ENSGALG00000012541); Dr: Danio rerio (Zebrafish) (BC065862); Cc: Cyprinus carpio (Common Carp) (D0338464 Isoform 2) (P02204 Isoform 1); OI: Oryzias latipes (Japanese Medaka) (ENSORLG00000004130); Mn: Makaira nigricans (Blue Marlin) (AF291833); Tn: Tetraodon nigroviridis (Spotted green pufferfish) (AJ628044); Tr: Takifugu rubripes (Japanese pufferfish): Ep: Euthynnus pelamis (Oceanic Bonito) (AF291837); Ar: Auxis rochei (Fregatte Makarel) (AB154423); To: Thunnus obesus (Bigeye tuna) (AB104433).
TABLE 1

\section{MYOGLOBIN EXPRESSION DOMAINS IN THE DEVELOPING ZEBRAFISH}

\begin{tabular}{ll} 
Embryonic stage & Expression domain \\
\hline prim-6 & eye, otic vesicle, gut \\
long-pec & $\begin{array}{l}\text { lens, retina, optic chiasm, otic vesicle, heart, intermandibularis posterior, } \\
\text { middle cerebral vein, cardinal vein, epidermis, gut, liver, pectoral fin } \\
\text { bud, telencephalon, diencephalon }\end{array}$ \\
& $\begin{array}{l}\text { eye, telencephalon, midbrain, hindbrain, otic vesicle, mandible, cephalic } \\
\text { musculature, branchial arches, heart, pectoral fin buds, intestine, liver, } \\
\text { epidermis, apical epidermis, peridermis, fin rays, floorplate, roofplate, } \\
\text { cardinal vein, intersegmental vessels } \\
\text { lens, retina, ganglion cell layer, inner nuclear layer, optic chiasm, } \\
\text { telencephalon, meckel's cartilage, basihyal, ceratohyal, palatoquadrate, } \\
\text { otic vesicle, sensory epithelium, midbrain, notochord, somites, pectoral } \\
\text { fin bud, liver, pancreas, intestine }\end{array}$ \\
\hline
\end{tabular}

$\mathrm{BC065862).} \mathrm{We} \mathrm{have} \mathrm{manually} \mathrm{annotated} \mathrm{the} \mathrm{zebrafish} \mathrm{Mb}$ gene, which is located on Chromosome 1 at location 64,311,869$64,314,844$ in the current release (Zv6) of the zebrafish genome project (Ensemble gene ID: ENSDARG00000031952; http:// www.ensembl.org/index.html).

Only a single zebrafish $\mathrm{Mb}$ gene was found to be encoded in the zebrafish genome. This is in contrast to the common carp for which two Mb forms have been described (Fraser et al., 2006). A detailed analysis of $\mathrm{Mb}$ intron exon structures in plants and animals can be found elsewhere (Dixon and Pohajdak, 1992).

We used protein sequences from different $\mathrm{Mb}$ homologues of 16 different vertebrate and 5 invertebrate species to perform a phylogenetic analysis (Fig. 1B). The results with high Bayesian support values reveal that whale myoglobin branches of after the rodents. A phylogeny of whale Mbs had been previously described (Iwanami et al., 2006). The unrooted phylogenetic tree in Figure 1 shows that, among the proteins analyzed, the closest homolog to zebrafish $\mathrm{Mb}$ was Mb2 of carp.

\section{Gene expression pattern of myoglobin during zebrafish de- velopment}

In this study, we have characterized the temporal and spatial expression patterns of $\mathrm{Mb}$ during early zebrafish development. Zebrafish embryos were staged according to Kimmel (Kimmel et al., 1995). Table 1 shows an overview of myoglobin expression domains during development. We found that $\mathrm{Mb}$ is present as a maternal RNA (Fig. 2A and B). It is ubiquitously expressed during gastrulation (at the shield stage in midgastrulation; Fig.2 C) and at the end of gastrulation (at tail bud stage; Fig. 2 D).

Distinct expression domains were observed at later stages of development. In prim- 6 embryos, $\mathrm{Mb}$ is expressed in the eye, the otic vesicle and the developing gut (Fig. $2 \mathrm{~F}$ ). Embryos at the long pec stage showed $\mathrm{Mb}$ expression in the eye (in the lens and retina), the metencephalic vein, the otic vesicle, the liver and in the gut. Staining was also detected in the epidermis and in the caudal vein (Fig. $2 \mathrm{E}, \mathrm{H}$ ).

At 4 days post fertilization (dpf) strong expression was observed at the anteriormost portion of the head. Staining was found in the eye, the telencephalon, the midbrain and hindbrain, the otic vesicle, the cephalic musculature, the mandible and the branchial arches. Strong expression was detected in the heart and fin rays. Expression was also observed in the epidermis, the peridermis and the apical epidermis of the pectoral fin buds. Additionally, in embryos at 4 days of development $\mathrm{Mb}$ was expressed in the intestine, the 


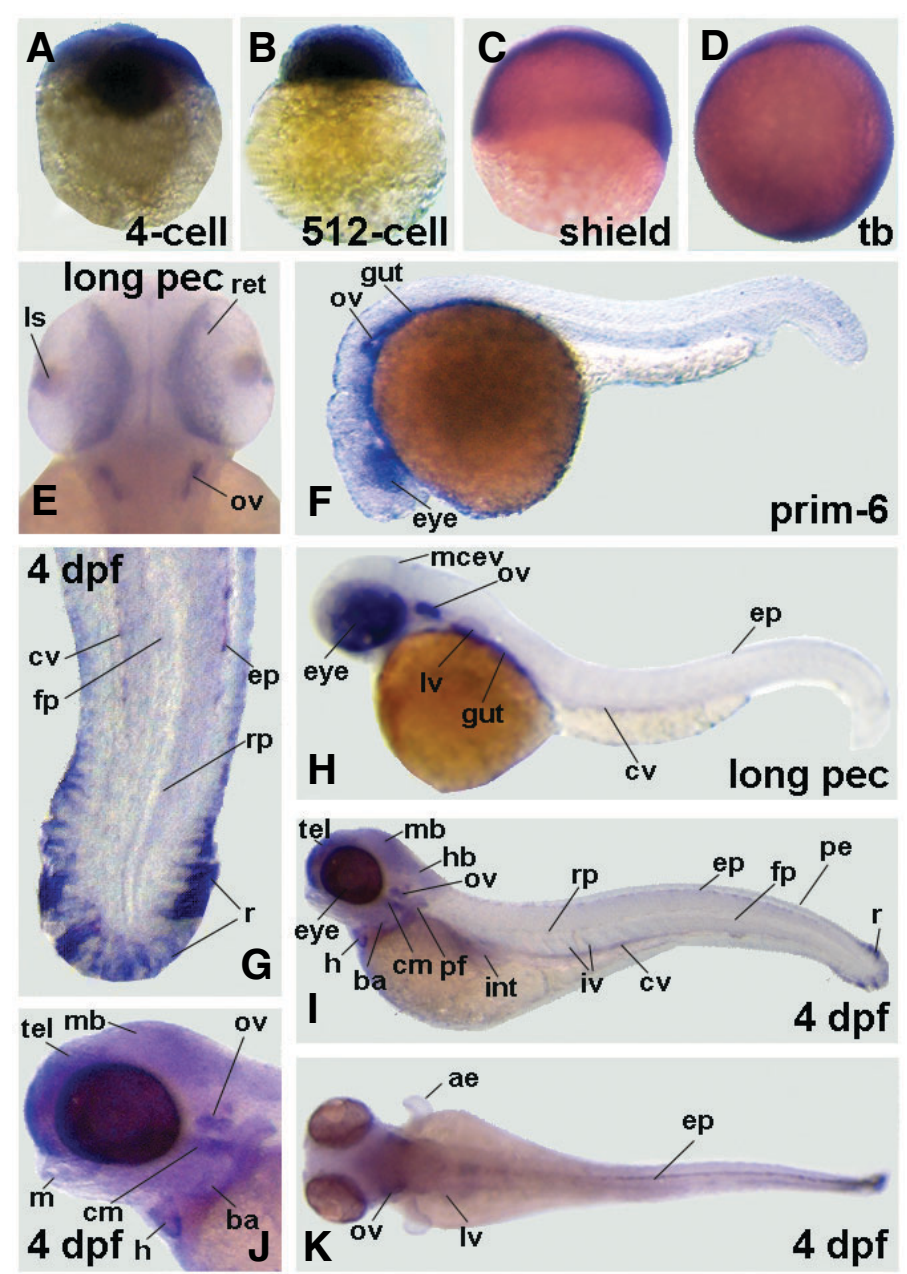

Fig. 2. Gene expression pattern of myoglobin during zebrafish development. The early embryos shown are during cleavage period at the 4-cell stage (A) followed by the 512-cell stage (B) shortly before mid blastula transition (MBT). Mid gastrulation is represented by shield stage embryos (C) and the end of gastrulation by embryos at tail bud stage (D). Later stages shown during the pharyngula period are: prim- 6 (F) and long pec stages $\mathbf{( E , H ) . ~ T h e ~ e a r l y ~ l a r v a l ~ p e r i o d ~ i s ~ r e p r e s e n t e d ~ b y ~ e m b r y o s ~ a t ~} 4$ dpf (G-K). Abbreviations used are: ae, apical epidermis; ba, branchial arches; cm, cephalic musculature; $c v$, caudal vein; ep, epidermis; $f p$, floorplate; h, heart; int, intestine; iv, intersegmental vessels; I, liver; Is, lens; $m$, mandibulae; mb, midbrain; mecv, midencephalic vein; ov, otic vesicle; pe, peridermis; pf, pectoral fin bud; $r$, fin rays; ret, retina and rp, roofplate.

liver, the floorplate, the roofplate, the caudal vein and in intersegmental vessels (Fig. 2 G, I, J and K).

To further characterize the gene expression pattern of $\mathrm{Mb}$ during zebrafish development, we investigated expression domains in sections of long pec and $5 \mathrm{dpf}$ embryos (Fig. 3). Sections of embryos at long pec stage and $5 \mathrm{dpf}$ showed distinct expression patterns for $\mathrm{Mb}$. At long pec stage $\mathrm{Mb}$ expression was found in the lens, the retina, the optic chiasm, the telencephalon and the diencephalon (Fig.3 A). In more posterior sections, staining was restricted to the epidermis and pectoral fin buds of embryos at the long pec stage (Fig. $3 \mathrm{~B}$ and $\mathrm{C}$ ). In embryos at $5 \mathrm{dpf}, \mathrm{Mb}$ was detected in the telencephalon, the telencephalon, the lens, the ganglion cell layer, the inner nuclear layer, the optic chiasm, the meckel's cartilage, the basihyal, ceratohyal and the palatoquadrate (Fig.3 D, E and F). More posterior parts of embryos at $5 \mathrm{dpf}$ showed expression in the otic vesicle, the sensory epithelium, the liver, the pancreas and the intestine. Weaker expression was also found in the midbrain, the notochord and the somites (Fig. $3 \mathrm{G}, \mathrm{H}, \mathrm{I}$ ).

\section{Influence of hypoxia on myoglobin gene expression in zebrafish embryos}

In this study we were interested in the effects of hypoxia on $\mathrm{Mb}$ gene expression during zebrafish development. We exposed zebrafish embryos to two hypoxic conditions (20\% air saturation: $5 \times 10^{-5} \mathrm{~mol} / \mathrm{l}$ or $1.6 \mathrm{mg} / \mathrm{I} \mathrm{O}_{2}$ and $10 \%$ air saturation: $2.5 \times 10^{-5} \mathrm{~mol} /$ I or $0.8 \mathrm{mg} / / \mathrm{O}_{2}$ ). Control zebrafish were kept under normoxic conditions ( $100 \%$ air saturation: $2.5 \times 10^{-4} \mathrm{~mol} / \mathrm{l}$ or $8 \mathrm{mg} / \mathrm{l} \mathrm{O}_{2}$ ). We observed that severe hypoxic conditions (10\%) led to increased $\mathrm{Mb}$ expression in the dorsal aorta and in skeletal muscles of anterior somites in early embryos (Fig. 4). This was observed in whole mount embryos (Fig. 4D) and in sections (Fig. 4E). Incubation in $20 \%$ air saturated water did not lead to a similar induction (Fig.4C). We confirmed these results by quantitative RT-PCR and observed a 1.7 fold induction of $\mathrm{Mb}$ (SD +/-0.06) expression in 48 hpf embryos exposed to $10 \%$ hypoxia (Fig. 4 F).

\section{Effects of myoglobin knock down on zebrafish development}

To better understand the regulatory and developmental functions of $\mathrm{Mb}$, we injected gene-specific morpholinos (MO) into zebrafish embryos and surveyed the phenotypic changes at
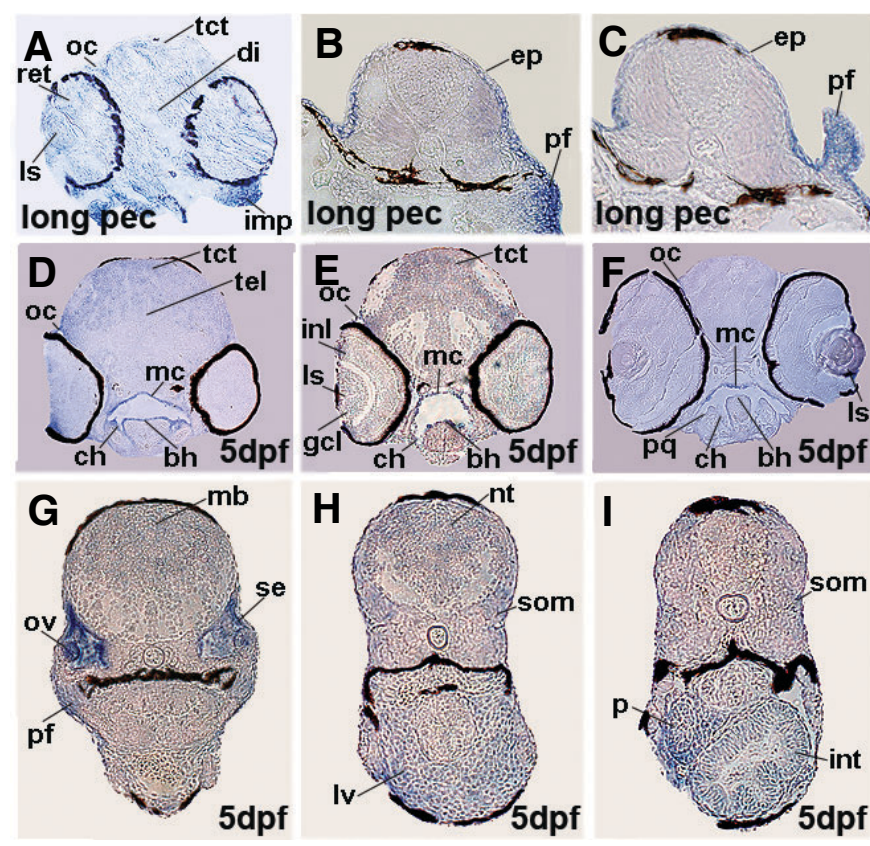

Fig. 3. Gene expression domains of myoglobin during zebrafish development in sections of long pec and $\mathbf{5 d p f}$ embryos. Shown are sections of whole mount in situ hybridized embryos at the indicated stages. Abbreviations used are: basihyal (bh), ceratohyal (ch), diencephaIon (di), epidermis (ep), ganglion cell layer (gcl), inner nuclear layer (inl), intermandibularis posterior (imp), intestine (int), liver (Iv), meckel's cartilage (mc), midbrain (mb), notochord ( $n t)$, optic chiasm (oc), otic vesicle (ov), palatoquadrate (pq), pancreas (p), sensory epithelium (se), somites (som) and telencephalon (tel). 
different stages of development (Fig. 5 and Table 2). We observed a dose dependent effect on the curvature of embryos. A low dose of $\mathrm{Mb}-\mathrm{MO}(1 \mathrm{ng})$ led to a minimal increase in the number of curved embryos (1.3\%) compared to control injected embryos (Table 2). Higher Mb-MO doses (2ng and 4ng) led to over $30 \%$ embryos with a curved body. We have categorized the extent of curvature into mild and severe (Fig. 5). More severely curved embryos were found when a high dose of $\mathrm{Mb}$ $\mathrm{MO}$ (4ng) was used compared to the lower Mb-MO dose (2ng) (Table 2). Slight differences to control embryos were visible at the 14 somite stage but curving was apparent only at $24 \mathrm{hpf}$ (Fig. 5). Both concentrations of Mb-MO also induced an enlarged pericardium in injected embryos (Fig. 5 and Table 2), which was not shown after injection of the control MO. We further observed an increase in lethality over time in the $\mathrm{Mb}$ knock down embryos.

Our findings that $\mathrm{Mb}$ is expressed in the caudal vein led us to further investigate a role of $\mathrm{Mb}$ in vascularization and angiogenesis. In order to test this, we injected Mb-MO) in a transgenic zebrafish line, Tg:fli1/eGFP (Lawson and Weinstein, 2002). The Tg:fli1/eGFP embryos express the green fluorescence protein under an early endothelial promotor and therefore exhibit a fluorescent green vasculature. Our results using laser scanning confocal microscopy showed that Mb knock down leads to angiogenesis defects (Fig. 6 and Table 3). Vascular defects were induced by $\mathrm{Mb}-\mathrm{MO}$ injections in a dose

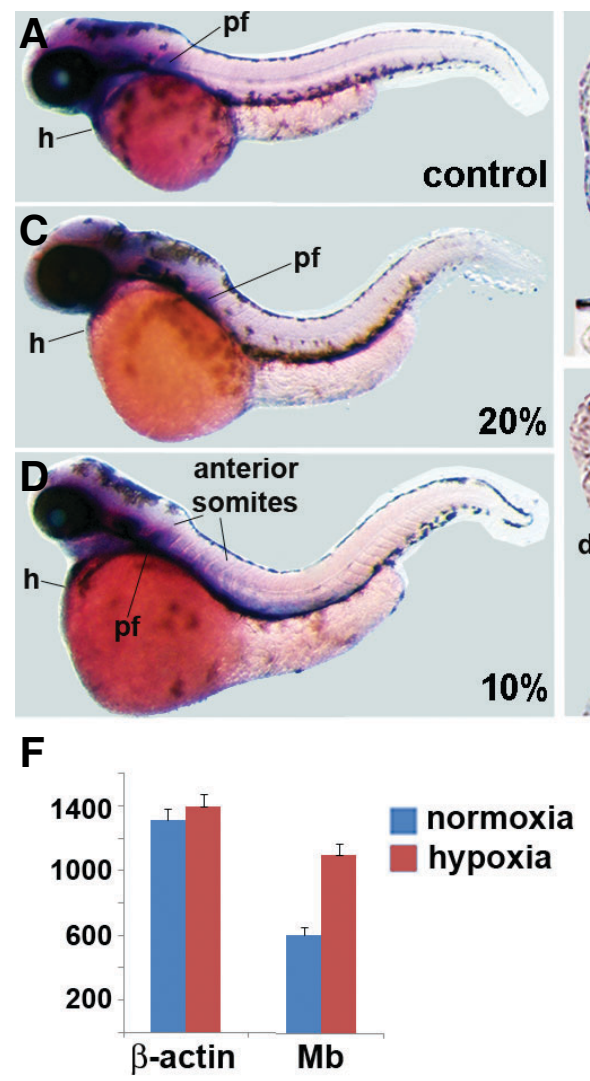

Fig. 4 (Left). Influence of hypoxia on myoglobin ( $\mathbf{M b}$ ) gene expression in zebrafish embryos. Zebrafish embryos were exposed to two different oxygen concentrations (10\% and $20 \%$ air saturated). Controls were kept
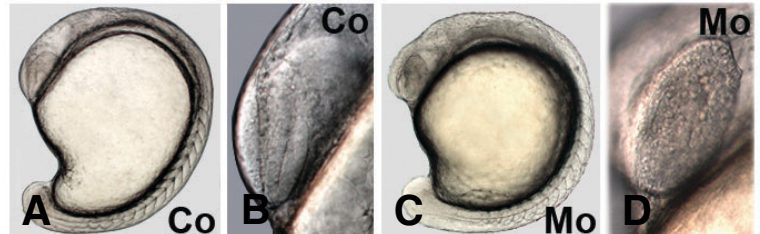

15 som

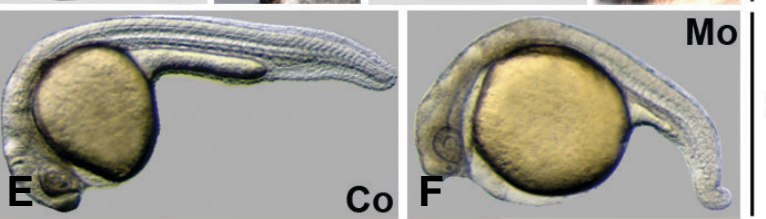

24hpf
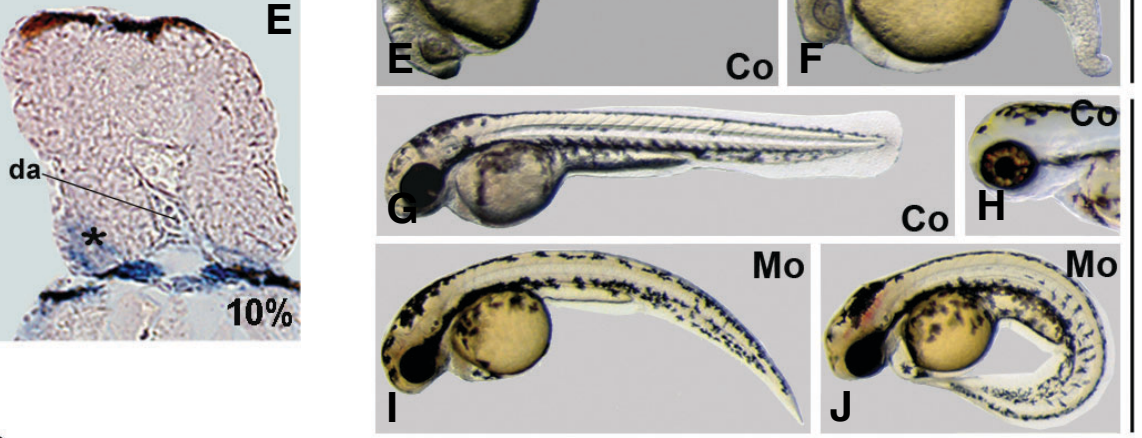

48hpf
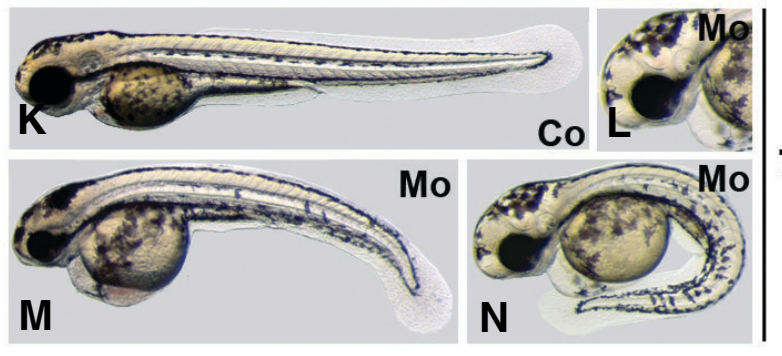

$72 \mathrm{hpf}$

at 100\% air saturated. Embryos were fixed at $48 \mathrm{hpf}$ for the control (A) and the $20 \%$ air saturated water embryos (C) and at $4 \mathrm{dpf}$ for the $10 \%$ air saturated water embryos (E) (which were strongly delayed in development). Fixed embryos were subjected to whole mount in situ hybridization. Blue and purple staining indicates myoglobin expression. Similar results were seen in five different specimen and staining in the anterior somites was never observed in control or $20 \%$ air saturated water embryos. Staining in the pectoral fins (pf) and in the heart (h) is indicated for all embryos and anterior somites and the dorsal aorta (da) are marked in the 10\% air saturated water embryos. In addition, shown are sections of the anterior somite area of control embryos (B) and embryos exposed to 10\% air saturated water (D). The latter shows stronger staining in regions of the anterior somites supporting the results of the whole mount pictures. Skeletal muscles are indicated with an asterisk and staining in the dorsal aorta (da) (D). The quantitative RT-PCR results for 48 hpf embryos under normoxic conditions or exposed to hypoxia (10\%) are shown in (F). Relative expression of myoglobin is given based on normalization to $\beta$-actin. A standard curve for $\beta$-actin was included in the experiments. Data represents two independent experiments each done in triplicates. In 48 hpf embryos, 10\% hypoxia led to a 1.7 fold induction of Mb normalized to actin (SD+/- 0.06).

Fig. 5 (Right). Effects of microinjection of myoglobin gene-specific Mo on zebrafish development. Shown are stereoscope pictures and DIC microscopy pictures of embryos and larvae at different stages of development. Embryos were injected at the one-cell stage with either a control Mo or the Mb specific MO (examples shown were injected with Mb-MO (2 ng/embryo (C,D, $\mathbf{F}, \mathbf{I}$ and $\mathbf{M})$ or 4 ng/embryo (J,L and $\mathbf{N})$ or control MO (4 ng) were used as indicated). 
TABLE 2

\section{MORPHOLINO INJECTIONS IN ZEBRAFISH EMBRYOS}

\begin{tabular}{|c|c|c|c|c|c|c|c|c|c|c|}
\hline \multirow[b]{2}{*}{$\begin{array}{l}\text { Morpholino } \\
\text { [amount] }\end{array}$} & \multirow[b]{2}{*}{ Injected } & \multicolumn{3}{|c|}{$24 \mathrm{hpf}$} & \multicolumn{3}{|c|}{$48 \mathrm{hpf}$} & \multicolumn{3}{|c|}{$72 \mathrm{~h}$} \\
\hline & & $\begin{array}{c}\text { Total } \\
\text { (\%survival) }\end{array}$ & $\begin{array}{l}\text { Curved phenotype } \\
\text { (mild/severe) }\end{array}$ & $\begin{array}{c}\text { Enlarged } \\
\text { Pericardium } \\
\text { (curved) }\end{array}$ & $\begin{array}{c}\text { Total } \\
\text { (\%survival) }\end{array}$ & $\begin{array}{c}\text { Curved phenotype } \\
\text { (mild/severe) }\end{array}$ & $\begin{array}{c}\text { Enlarged } \\
\text { Pericardium } \\
\text { (curved) }\end{array}$ & $\begin{array}{c}\text { Total } \\
\text { (\%survival) }\end{array}$ & $\begin{array}{c}\text { Curved phenotype } \\
\text { (mild/severe) }\end{array}$ & $\begin{array}{c}\text { Enlarged } \\
\text { Pericardium } \\
\text { (curved)) }\end{array}$ \\
\hline $\begin{array}{l}\text { Control } \\
{[4 \mathrm{ng}]}\end{array}$ & 766 & 722 (94\%) & 0 & 0 & $690(90 \%)$ & 0 & 0 & $686(90 \%)$ & 0 & 0 \\
\hline $\begin{array}{c}\mathrm{Mb} \\
{[1 \mathrm{ng}]}\end{array}$ & 85 & 79 (93\%) & $\begin{array}{c}1(1 / 0) \\
1.3 \%\end{array}$ & $\begin{array}{l}1(1) \\
1.3 \%\end{array}$ & 76 (89\%) & 0 & 0 & 73 (86\%) & 0 & 0 \\
\hline $\begin{array}{c}\mathrm{Mb} \\
{[2 \mathrm{ng}]}\end{array}$ & 630 & 548 (87\%) & $\begin{array}{c}215(142 / 73) \\
39.2 \%\end{array}$ & $\begin{array}{c}266(215) \\
49 \%\end{array}$ & $485(77 \%)$ & $\begin{array}{c}135(90 / 45) \\
27.8 \%\end{array}$ & $\begin{array}{c}186(135) \\
38.3 \%\end{array}$ & 446 (71\%) & $\begin{array}{c}108(71 / 37) \\
24.2 \%\end{array}$ & $\begin{array}{c}134(108) \\
30.0 \%\end{array}$ \\
\hline $\begin{array}{c}\mathrm{Mb} \\
{[4 \mathrm{ng}]}\end{array}$ & 706 & $636(90 \%)$ & $\begin{array}{c}235(78 / 157) \\
36.9 \%\end{array}$ & $\begin{array}{c}233(233) \\
36.6 \%\end{array}$ & $566(80 \%)$ & $\begin{array}{c}174(57 / 117) \\
30.7 \%\end{array}$ & $\begin{array}{c}180(172) \\
31.8 \%\end{array}$ & 506 (72\%) & $\begin{array}{c}115(45 / 70) \\
22.7 \%\end{array}$ & $\begin{array}{c}120(114) \\
23.7 \%\end{array}$ \\
\hline
\end{tabular}

dependent manner (Table 3). In the Mb-MO injected embryos, we observed an impaired formation of dorsal longitudinal anastomotic vessels (DLAV) with several of these connective vessels missing (Fig. 6).

Our expression study also showed that $\mathrm{Mb}$ is strongly expressed in the gut of the developing zebrafish embryos. To test the hypothesis that Mb plays a role in gut development, we used a gut-GFP transgenic zebrafish line, which expresses GFP under the EF-1 $\alpha$ promotor (Tg:ef-1 $\alpha /$ eGFP) (Field et al., 2003).

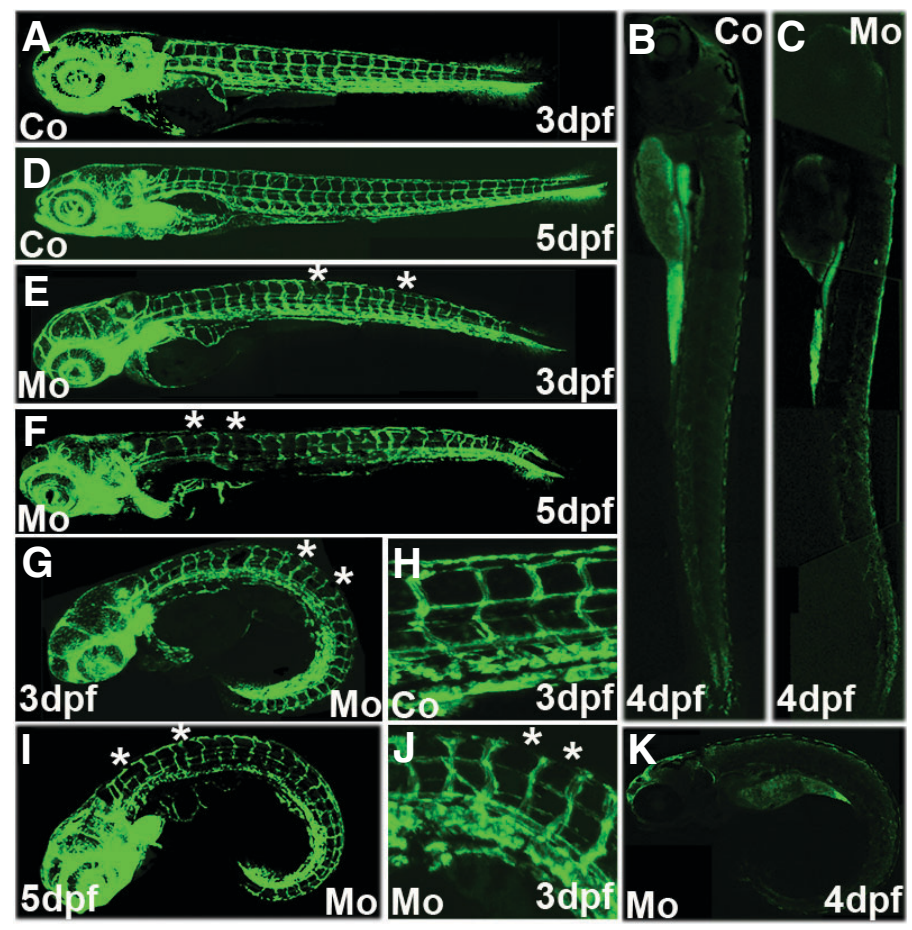

Fig. 6. Effects of microinjection of myoglobin gene-specific morpholinos in Tg:fli1/eGFP and Gut/GFP transgenic fish. Tg:fli1/eGFP embryos (A, D-J) and Gut/GFP (Tg:ef-1 $\alpha /$ eGFP) (B,C,K) were injected with 4 ng/embryo of either Control Morpholino (Co) or Mb specific Morpholino (Mo) as indicated. Zebrafish larvae at three different time points are shown: $3 \mathrm{dpf}, 4 \mathrm{dpf}$ and $5 \mathrm{dpf}$. The fluorescent gut is not well visible before $4 \mathrm{dpf}$. All pictures show confocal images of representative examples for control and knock down embryos. Higher magnification images $\mathbf{( H , J ) ~ g i v e ~ e x a m p l e s ~ f o r ~ a ~ c o n t r o l ~} \mathbf{( H )}$ and an $\mathrm{Mb}$ knock down $(\mathbf{J})$ embryo, respectively. An asterisk is used to mark representative sites of vascular defects (E-G, I,J) (not all defects are marked).
The gut-GFP embryos exhibit a green fluorescent gut, which initially becomes visible at $72 \mathrm{hpf}$. The Mb-MO injected embryos did show a reduced size of the gut in over $30 \%$ of cases (Table 3 and Fig. 6). These findings indicate that Mb could play a role in gut development.

\section{Discussion}

Although $\mathrm{Mb}$ is, like most of the globins, a very well studied molecule, there is very limited amount of information available on its expression and function during vertebrate embryogenesis. Longo et al. (1973) had compared the Mb protein levels in different vertebrate embryos but focused their study on muscle tissue extracts (Longo et al., 1973). Another study using northern blot analysis focused also solely on muscle tissues and described embryonic gene expression in RNA preparations of cardiac and skeletal muscle (Weller et al., 1986). No in situ data on spatial and/ or temporal expression of $\mathrm{Mb}$ gene expression in vertebrates has been published up to date.

We were particularly interested in the identifying non-muscle related expression domains for $\mathrm{Mb}$. Mb expression during development was found in several organs e.g. brain, pancreas, liver

TABLE 3

\section{MORPHOLINO INJECTIONS IN TG:FLI1/EGFP AND TG:EF-1 $\alpha /$ EGFP ZEBRAFISH EMBRYOS}

\begin{tabular}{|c|c|c|c|}
\hline $\begin{array}{c}\text { Tg:fli1/eGFP } \\
\text { Morpholino } \\
\text { [amount] }\end{array}$ & Total & Vascular defects & $\begin{array}{l}\text { Curved phenotype } \\
\text { (mild/severe) }\end{array}$ \\
\hline $\begin{array}{c}\text { Control } \\
{[4 \mathrm{ng}]}\end{array}$ & 150 & 0 & $0 / 0$ \\
\hline $\begin{array}{c}\mathrm{Mb} \\
{[1 \mathrm{ng}]}\end{array}$ & 71 & $3(4.2 \%)$ & $0 / 0$ \\
\hline $\begin{array}{c}\mathrm{Mb} \\
{[2 \mathrm{ng}]}\end{array}$ & 207 & $53(25.6 \%)$ & $27 / 15$ \\
\hline $\begin{array}{c}\mathrm{Mb} \\
{[4 \mathrm{ng}]}\end{array}$ & 121 & $48(31.4 \%)$ & $16 / 29$ \\
\hline \multicolumn{4}{|l|}{ Tg:ef1 $\alpha /$ eGFP } \\
\hline $\begin{array}{c}\text { Morpholino } \\
\text { [amount] }\end{array}$ & Total & Gut defects & $\begin{array}{l}\text { Curved phenotype } \\
\text { (mild/severe) }\end{array}$ \\
\hline $\begin{array}{c}\text { Control } \\
{[4 \mathrm{ng}]}\end{array}$ & 200 & 0 & $0 / 0$ \\
\hline $\begin{array}{c}\mathrm{Mb} \\
{[1 \mathrm{ng}]}\end{array}$ & 80 & 0 & $0 / 0$ \\
\hline $\begin{array}{c}\mathrm{Mb} \\
{[2 \mathrm{ng}]}\end{array}$ & 112 & $34(30.3 \%)$ & $18 / 14$ \\
\hline $\begin{array}{c}\mathrm{Mb} \\
{[4 \mathrm{ng}]}\end{array}$ & 120 & $44(36.6 \%)$ & $10 / 30$ \\
\hline
\end{tabular}


and gut. It is possible that $\mathrm{Mb}$ is involved in organogenesis and plays important roles during embryonic development other than related to muscle development. Our findings show that Mb knock down leads to morphological and anatomical defects. We observed severe bending of the embryos. Since injected embryos did not show any visible defects at the end of gastrulation, and at the tail bud stage (data not shown), the curvature of the embryo takes place at a later time point of development. Therefore, defects during gastrulation e.g. imperfect convergent extension movements can be ruled out as a cause for the curvature. $A$ plausible explanation for the observed bending is a defect in muscle function and/or development. This muscle defect could be either directly related to the lack of $\mathrm{Mb}$ expression in the muscle cells, or indirectly by a limited oxygen supply to muscle cells due to vascular defects.

In this study, we observed vascular defects in Mb knock down embryos. There are no indications that absence of $\mathrm{Mb}$ is mechanistically involved in angiogenesis, but lack of Mb could affect vascularization indirectly. In addition to its role in oxygen transport, in mouse heart $\mathrm{Mb}$ has been shown to dioxygenate nitrogen oxide (NO) and reduce levels of hydrogen peroxide as well as superoxide (Flogel et al., 2004, Flogel et al., 2001). Lack of Mb in knock down embryos might lead to reduced scavenging of $\mathrm{NO}$, causing locally elevated levels. This could in turn cause impaired vascularization, as has been described in the chick embryo chorioallantoic membrane assay and in cultured human umbilical vein endothelial cells (Cartwright et al., 2000, Pipili-Synetos et al., 1994). Substantial evidence also indicates that NO is positively related to angiogenesis in embryonic and mature tissues (Al-Ani et al., 2006, Namba et al., 2003, Nath et al., 2004, Papapetropoulos et al., 1997). The roles of $\mathrm{Mb}$ in regulating $\mathrm{NO}$ levels in the developing zebrafish and in vascularization remain to be determined.

Another way by which Mb knock down could lead to vascular defects is that the smooth muscle cells, surrounding the endothelial cells in blood vessels do not develop properly, due to lack of $\mathrm{Mb}$. In human and chicken, Mb has been detected in smooth muscle of uterus, intestine and rectus tissues (Qiu, 1998, Schuder, 1979). Here, we detect weak Mb expression along the caudal vein, which is likely to be in the smooth muscle cells of these veins. The presences of $\mathrm{Mb}$ in smooth muscle cells suggests that it may play a role in oxygen delivery to the core of these cells and/or in $\mathrm{NO}$ induced vasodilation. However, Mb could also prevent excessively high levels of hydrogen peroxide, superoxide and/or NO and thereby protect smooth muscle cells from structural damage.

In zebrafish embryos, an enlarged pericardium, which is usually induced by an edema, is an indication for either a heart and/ or a circulation defect. Earlier results in $\mathrm{Mb}$ deficient mice showed, that the majority of embryos lacking $\mathrm{Mb}$ die in utero at midgestation with signs of cardiac failure (Meeson et al., 2001). We found here strong $\mathrm{Mb}$ expression in the developing zebrafish heart. Taken together, this could suggest that cardiac defects are responsible for the enlarged pericardia we found in Mb knock down embryos. Another possibility is that the strong curvature and/or the vessel defects lead to circulatory interruptions in the embryo and caused the edema. Finally, all of these three alternatives could contribute to some extend to the enlargement of the pericardium and the observed increase in lethality over time observed in Mb knock down embryos. Similarly, the reduced gut found in the Mb knock down embryos could be a consequence of the vascularization defects and/or the severe bending of the embryos. It is possible that $\mathrm{Mb}$ is expressed in smooth muscle cells in the gut and this might be important for proper gut development.

The question is raised whether knock down of $\mathrm{Mb}$ in cardiac myocytes caused cardiac failure prior to impaired angiogenesis. If so, the compromised cardiac function will cause a reduced flow of erythroblasts and as a consequence a lower shear stress in the circulation system. Recently, hemodynamic force has been shown to be necessary for vascular remodeling of the mouse yolk sac (Lucitti et al., 2007). We hypothesize that the vascular defects observed in $\mathrm{Mb}-\mathrm{MO}$ are due to elevated $\mathrm{NO}$ signaling and/or cardiac dysfunction.

Recently, it has been shown that severe hypoxic conditions lead to a developmental delay in zebrafish embryos"(Kajimura et al., 2005, Padilla and Roth, 2001). In adult zebrafish, we and others showed that hypoxia leads to increased $\mathrm{Mb}$ expression in different tissues (Roesner et al., 2006, van der Meer et al., 2005). Similar results were found in the liver of adult carp (Fraser et al., 2006). Moreover, endurance swim training of zebrafish embryos led to enhanced $\mathrm{Mb}$ expression in skeletal muscle (van der Meulen et al., 2006). All these previous studies suggested a possible regulation of $\mathrm{Mb}$ expression by hypoxia in zebrafish embryos. Indeed our findings show that Mb expression is induced in developing embryos exposed to severe hypoxia. This could point to a potential adaptive response to hypoxia during embryonic development in order to regulate diverse processes (i.e. cellular oxygenation and NO metabolisms) (Riggs, 2006). Further research is warranted to identify a possible mechanism and the exact function of this regulation.

In summary, we have identified here novel non-muscular expression domains for the $\mathrm{Mb}$ gene and showed that zebrafish development is critically dependent on $\mathrm{Mb}$ expression.

\section{Materials and Methods}

\section{Animal care, handling and hypoxia treatment}

Zebrafish were handled in compliance with local animal care regulations and standard protocols. Fish were kept at $28^{\circ} \mathrm{C}$ in aquaria with standard day/night light cycles. The developing embryos were kept at $28^{\circ} \mathrm{C}$ under two hypoxic conditions $\left(20 \%\right.$ air saturation: $1.6 \mathrm{mg} / \mathrm{l} \mathrm{O}_{2}$ and 10\%: $0.8 \mathrm{mg} / \mathrm{l}_{2}$ ). A normoxic control group (100\% air saturation: $8 \mathrm{mg} /$ $\mathrm{I}_{2}$ ) was kept in identical aquaria of 100 liters. The oxygen level on the hypoxia group was kept constant by a controller (Applicon) connected to an oxygen electrode and solenoid valve in line with an air diffuser. The oxygen concentration level in the tank was kept constant by adding oxygen via the diffuser and thereby compensating the oxygen consumption of the embryos.

\section{Cloning of zebrafish myoglobin}

Whole zebrafish RNA was obtained from liquid nitrogen frozen adult fish through Trizol ${ }^{\circledR}$ (GIBCOBRL, Life technologies) extraction according to the manufacturer's instructions. The complete open reading frames were amplified by RT-PCR, using a SuperScriptlll kit (Invitrogen) in concert with flanking primers based on $\mathrm{Mb}$ sequences. The primers used were: 5' tcttcacagaggacaaacacc 3' (forward) and 5' cgctttatttatgactcccattt 3' (reverse).

\section{Sequence alignment and phylogenetic analysis}

The amino acid alignment of the zebrafish $\mathrm{Mb}$ gene was made using ClustalX"(Thompson et al., 1997) and subsequently processed and 
manually refined using Genedoc software (http://www.psc.edu/biomed/ genedoc/). The phylogenetic tree was generated employing MrBayes (Huelsenbeck and Ronquist, 2001) version 3.1. The number of generations was set at 5000000 , sampled every $100^{\text {th }}$ generation, while 1250 trees were discarded as burnin. The consensus tree and Bayesian numbers were saved in a final figure with Treeview (Page, 1996).

\section{Whole mount in situ hybridization and sectioning of whole mount embryos}

The in situ hybridization procedure was modified from the Thisse protocol (Thisse et al., 1993) and has been previously described (te Velthuis et al., 2007). An antisense oligonucleotide probe corresponding to the full length zebrafish $\mathrm{Mb}$ coding sequence of $444 \mathrm{bp}$ was used in the experiments. After in situ hybridization, embryos were fixed overnight in $4 \%$ PFA in PBS, at $4{ }^{\circ} \mathrm{C}$. They were subsequently dehydrated through an alcohol series: $70 \%, 80 \%, 90 \%$ and $3 \times 100 \%$ ethanol, 1 h each. Next, they were transferred into Xylene, $3 \times 30 \mathrm{~min}$. Finally, the embryos were transferred into paraffin, $3 \times 2 \mathrm{~h} .8 \mu \mathrm{m}$ sections were cut with a ReichterJung Ultracut micrometer (Leica). Pictures were taken in Axioplan 2 microscope (Carl Zeiss) using AxioVision 4 software.

\section{RNA isolation and quantitative RT-PCR}

RNA preparation was described before (Ott et al., 2007) and a pool of 100 embryos was used per isolation. For Real-time quantitative RT-PCR the Roche Master SYBR Green kit was used. The annealing and synthesis temperature was $55^{\circ} \mathrm{C}$ alternating with $96^{\circ} \mathrm{C}$ for 45 cycles. Dissociation protocols were used to measure melting curves and control for unspecific signals from the primers. We used $100 \mathrm{ng}$ of total RNA per reaction. A standard curve for $\beta$-actin using $1,5,10,100$, and $500 \mathrm{ng}$ of total RNA was used for normalization. Samples were measured in the Roche LightCycler. The Primer3 software (http://frodo.wi.mit.edu/cgi-bin/ primer3/primer3_www.cgi) was used to design primers for short amplicons between 50 and 100 bases using. Primers used for zebrafish $\beta$-Actin were previously described (Marques et al., 2008). The primer sequences for zebrafish myoglobin were: Forward: 5-tcaaaccactggccaataca-3 and Reverse: 5- agttgttgagggccactttg-3.

\section{Targeted gene knock-down with myoglobin morpholinos}

$\mathrm{A} \mathrm{Mb}$ antisense morpholino oligonucleotides (Mb-MO) was designed (Gene Tools). The Mb-MO sequence is:

5'-CAGAACCAGATCATGATCAGCCATC-3'

The Mo was dissolved in water to a $4 \mathrm{mM}$ stock solution which was stored at $-80^{\circ} \mathrm{C}$. The stock of the respective Mo was thawed and diluted in Danieau's solution $(58 \mathrm{mmol} / \mathrm{L} \mathrm{NaCl}, 7 \mathrm{mmol} / \mathrm{L} \mathrm{KCl}, 0.4 \mathrm{mmol} / \mathrm{L}$ $\mathrm{MgSO} 4,6.0 \mathrm{mmol} / \mathrm{L} \mathrm{Ca}(\mathrm{NO} 3) 2$, and $5.0 \mathrm{mmol} / \mathrm{L} \mathrm{HEPES} \mathrm{pH} 7.6$ ) to the working condition of which $1 \mathrm{nl}$ was injected into the yolk of 1- to 2-cell stage embryos. For the experiments, a standard control morpholino was used with the sequence: 52 CCTCTTACCTCAGTTACAATTTATA 32. This oligo has no target and was shown to have no significant biological activity (Gene Tools, LLC).

\section{Acknowledgements}

We are grateful to the Weinberg and Stainier Labs for creating and making the Fli1-GFP and the Gut-GFP transgenic lines available. We further like to thank David de Witt for animal care.

\section{References}

AL-ANI, B., HEWETT, P.W., AHMED, S., CUDMORE, M., FUJISAWA, T., AHMAD, S. and AHMED, A. (2006). The Release of Nitric Oxide from S-Nitrosothiols Promotes Angiogenesis. PLOS ONE 1: e25.

CARTWRIGHT, J.E., JOHNSTONE, A.P. and WHITLEY, G.S.J. (2000). Endogenously produced nitric oxide inhibits endothelial cell growth as demonstrated using novel antisense cell lines. Br. J. Pharmacol. 131: 131-137.

DIXON, B. and POHAJDAK, B. (1992). Did the ancestral globin gene of plants and animals contain only two introns? Trends Biochem. Sci. 17: 486-488.

FIELD, H.A., DONG, P.D.S., BEIS, D. and STAINIER, D.Y.R. (2003). Formation of the digestive system in zebrafish. ii. pancreas morphogenesis. Dev. Biol. 261: 197-208.

FLOGEL, U., GODECKE, A., KLOTZ, L.O. and SCHRADER, J. (2004). Role of myoglobin in the antioxidant defense of the heart. FASEB J. 18: 1156-8.

FLOGEL, U., MERX, M.W., GODECKE, A., DECKING, U.K.M. and SCHRADER, J. (2001). Myoglobin: A scavenger of bioactive NO. Proc. Natl. Acad. Sci. USA 98: 735-740.

FRASER, J., DE MELLO, L.V., WARD, D., REES, H.H., WILLIAMS, D.R., FANG, Y., BRASS, A., GRACEY, A.Y. and COSSINS, A.R. (2006). Hypoxia-inducible myoglobin expression in nonmuscle tissues. Proc. Natl. Acad. Sci. USA 103: 2977-2981.

GARRY, D.J., ORDWAY, G.A., LORENZ, J.N., RADFORD, N.B., CHIN, E.R., GRANGE, R.W., BASSEL-DUBY, R. and WILLIAMS, R.S. (1998). Mice without myoglobin. Nature 395: 905-908.

GODECKE, A., FLOGEL, U., ZANGER, K., DING, Z., HIRCHENHAIN, J., DECKING, U.K.M. and SCHRADER, J. (1999). Disruption of myoglobin in mice induces multiple compensatory mechanisms. Proc. Natl. Acad. Sci. USA 96: 10495-10500.

HUELSENBECK, J.P. and RONQUIST, F. (2001). MRBAYES: Bayesian inference of phylogenetic trees. Bioinformatics 17: 754-755.

IWANAMI, K., MITA, H., YAMAMOTO, Y., FUJISE, Y., YAMADA, T. and SUZUKI, T. (2006). cDNA-derived amino acid sequences of myoglobins from nine species of whales and dolphins. Comp. Biochem. Physiol. B: Biochem. Mol. Biol. 145: 249-256.

KAJIMURA, S., AIDA, K. and DUAN, C. (2005). From the Cover: Insulin-like growth factor-binding protein-1 (IGFBP-1) mediates hypoxia-induced embryonic growth and developmental retardation. Proc. Natl. Acad. Sci. USA 102: 1240-1245.

KIMMEL, C.B., BALLARD, W.W., KIMMEL, S.R., ULLMANN, B. and SCHILLING, T.F. (1995). Stages of embryonic development of the zebrafish. Dev. Dynam. 203: 253-310.

LAWSON, N.D. and WEINSTEIN, B.M. (2002). In vivo Imaging of Embryonic Vascular Development Using Transgenic Zebrafish. Dev. Biol. 248: 307-318.

LEE-DE GROOT, M.B.E., DES TOMBE, A.L. and VAN DER LAARSE, W.J. (1998). Calibrated Histochemistry of Myoglobin Concentration in Cardiomyocytes. J. Histochem. Cytochem. 46: 1077-1084.

LONGO, L.D., KOOS, B.J. and POWER, G.G. (1973). Fetal myoglobin: quantitative determination and importance for oxygenation. Am J Physiol 224: 1032-1036.

LUCITTI, J.L., JONES, E.A.V., HUANG, C., CHEN, J., FRASER, S.E. and DICKINSON, M.E. (2007). Vascular remodeling of the mouse yolk sac requires hemodynamic force. Development 134: 3317-3326.

MADDEN, P.W., BABCOCK, M.J., VAYDA, M.E. and CASHON, R.E. (2004). Structural and kinetic characterization of myoglobins from eurythermal and stenothermal fish species. Comp. Biochem. Physiol. B: Biochem. Mol. Biol. 137: 341-350.

MARQUES, I., LEITO, J., SPAINK, H., TESTERINK, J., JASPERS, R., WITTE, F., VAN DEN BERG, S. and BAGOWSKI, C. (2008). Transcriptome analysis of the response to chronic constant hypoxia in zebrafish hearts. J. Comp. Physiol. 178: 77-92.

MEESON, A.P., RADFORD, N., SHELTON, J.M., MAMMEN, P.P., DIMAIO, J.M., HUTCHESON, K., KONG, Y., ELTERMAN, J., WILLIAMS, R.S. and GARRY, D.J. (2001). Adaptive mechanisms that preserve cardiac function in mice without myoglobin. Circ. Res. 88: 713-720.

NAMBA, T., KOIKE, H., MURAKAMI, K., AOKI, M., MAKINO, H., HASHIYA, N., OGIHARA, T., KANEDA, Y., KOHNO, M. and MORISHITA, R. (2003). Angiogenesis Induced by Endothelial Nitric Oxide Synthase Gene Through Vascular Endothelial Growth Factor Expression in a Rat Hindlimb Ischemia Model. Circulation 108: 2250-2257.

NATH, A.K., ENCISO, J., KUNIYASU, M., HAO, X.-Y., MADRI, J.A. and PINTER, E. (2004). Nitric oxide modulates murine yolk sac vasculogenesis and rescues glucose induced vasculopathy. Development 131: 2485-2496.

ORDWAY, G.A. and GARRY, D.J. (2004). Myoglobin: an essential hemoprotein in striated muscle. J. Exp. Biol. 207: 3441-3446.

OTT, E.B., TE VELTHUIS, A.J.W. and BAGOWSKI, C.P. (2007). Comparative 
analysis of splice form-specific expression of LIM Kinases during zebrafish development. Gene Expr. Patterns 7: 620-629.

PADILLA, P.A. and ROTH, M.B. (2001). Oxygen deprivation causes suspended animation in the zebrafish embryo. Proc. Natl. Acad. Sci. USA 98: 7331-7335.

PAGE, R.D.M. (1996). TREEVIEW: An application to display phylogenetic trees on personal computers. Comput. Appl. Biosci. 12: 357-358.

PAPAPETROPOULOS, A., GARCÍA-CARDEÑA G, MADRI JA and WC, S. (1997). Nitric oxide production contributes to the angiogenic properties of vascular endothelial growth factor in human endothelial cells. J. Clin. Invest. 100: 31313139.

PESCE A., BOLOGNESI M., BOCEDI A., ASCENZI P., DEWILDE S., MOENS L., HANKELN T. and BURMESTER T. (2002). Neuroglobin and cytoglobin. Fresh blood for the vertebrate globin family. EMBO Rep. 3: 1146-1151.

PIPILI-SYNETOS, E., SAKKOULA E, HARALABOPOULOS G, ANDRIOPOULOU P, PERISTERIS P and ME., M. (1994). Evidence that nitric oxide is an endogenous antiangiogenic mediator. Br. J. Pharmacol. 111: 894-902.

QIU, Y., SUTTON L \& RIGGS AF (1998). Identification of myoglobin in human smooth muscle. J. Biol. Chem. 273: 23426-23432.

RIGGS, A.G.T. (2006). A globin in every cell?. Proc. Natl. Acad. Sci. USA 103: 24692470.

ROESNER, A., HANKELN, T. and BURMESTER, T. (2006). Hypoxia induces a complex response of globin expression in zebrafish (Danio rerio). J. Exp. Biol. 209: 2129-2137.

SCHUDER, S., WITTENBERG JB, HASELTINE B \& WITTENBERG BA (1979). Spectrophotometric determination of myoglobin in cardiac and skeletal muscle: separation from hemoglobin by subunit-exchange chromatography. Anal. Biochem. 92: 473-481.

SUZUKI, T. and IMAI, K. (1998). Evolution of myoglobin. Cell Mol.Life Sci. 54: 9791004.
TAKAHASHI, E. and DOI, K. (1998). Impact of diffusional oxygen transport on oxidative metabolism in the heart. Jpn. J. Physiol. 48: 243-252.

TE VELTHUIS, A.J.W., OTT, E.B., MARQUES, I.J. and BAGOWSKI, C.P. (2007). Gene expression patterns of the ALP family during zebrafish development. Gene Expr. Patterns 7: 297-305.

THISSE, C., THISSE, B., SCHILLING, T.F. and POSTLETHWAIT, J.H. (1993). Structure of the zebrafish snail1 gene and its expression in wild-type, spadetail and no tail mutant embryos. Development 119: 1203-1215.

THOMPSON, J.D., GIBSON, T.J., PLEWNIAK, F., JEANMOUGIN, F. and HIGGINS, D.G. (1997). The CLUSTAL_X windows interface: flexible strategies for multiple sequence alignment aided by quality analysis tools. Nucleic Acids Res. 25: 4876-4882.

VAN DER MEER, D.L., VAN DEN THILLART, G.E., WITTE, F., DE BAKKER, M.A., BESSER, J., RICHARDSON, M.K., SPAINK, H.P., LEITO, J.T. and BAGOWSKI, C.P. (2005). Gene expression profiling of the long-term adaptive response to hypoxia in the gills of adult zebrafish. Am. J. Physiol. Regul. Integr. Comp. Physiol. 289: R1512-1519.

VAN DER MEULEN, T., SCHIPPER, H., VAN DEN BOOGAART, J.G.M., HUISING, M.O., KRANENBARG, S. and VAN LEEUWEN, J.L. (2006). Endurance exercise differentially stimulates heart and axial muscle development in zebrafish (Danio rerio). Am. J. Physiol. Regul. Integr. Comp. Physiol. 291: R1040-1048.

VINOGRADOV, S.N., HOOGEWIJS, D., BAILLY, X., ARREDONDO-PETER, R., GOUGH, J., DEWILDE, S., MOENS, L. and VANFLETEREN, J.R. (2006). A phylogenomic profile of globins. BMC Evol. Biol. 6: 31.

WELLER, P.A., PRICE, M., ISENBERG, H., EDWARDS, Y.H. and JEFFREYS, A.J. (1986). Myoglobin expression: early induction and subsequent modulation of myoglobin and myoglobin mRNA during myogenesis. Mol. Cell Biol. 6: 45394547.

WITTENBERG, J.B. and WITTENBERG, B.A. (2003). Myoglobin function reassessed. J. Exp. Biol. 206: 2011-2020. 
Further Related Reading, published previously in the Int. J. Dev. Biol.

See our recent Special Issue Fertilization, in honor of David L. Garbers and edited by Paul M. Wassarman and Victor D. Vacquier at: http://www.ijdb.ehu.es/web/contents.php?vol=52\&issue=5-6

Developmentally regulated expression of hemoglobin subunits in avascular tissues

Fiona C. Mansergh, Susan M. Hunter, Jenny C. Geatrell, Miguel Jarrin, Kate Powell, Martin J. Evans and Michael A. Wride Int. J. Dev. Biol. (2008) 52: 52: 873 - 886 doi: 10.1387/ijdb.082597fm

In vivo forced expression of myocardin in ventricular myocardium transiently impairs systolic performance in early neonatal pig heart

Mario Torrado, Alberto Centeno, Eduardo López and Alexander T. Mikhailov

Int. J. Dev. Biol. (2008) 52: doi: 10.1387/ijdb.072366mt

Embryonic development of the proepicardium and coronary vessels

Anna Ratajska, Elzbieta Czarnowska and Bogdan Ciszek

Int. J. Dev. Biol. (2008) 52: 229-236

Biophysical regulation during cardiac development and application to tissue engineering

Sharon Gerecht-Nir, Milica Radisic, Hyoungshin Park, Christopher Cannizzaro, Jan Boublik, Robert Langer and Gordana Vunjak-

Novakovic

Int. J. Dev. Biol. (2006) 50: 233-243

Notch in vertebrates - molecular aspects of the signal

Ken-Ichi Katsube and Kei Sakamoto

Int. J. Dev. Biol. (2005) 49: 369-374

Vasculogenesis and angiogenesis in the mouse embryo studied using quail/mouse chimeras Michel Pudliszewski and Luc Pardanaud

Int. J. Dev. Biol. (2005) 49: 355-361

Vascular development: from precursor cells to branched arterial and venous networks

Anne Eichmann, Li Yuan, Delphine Moyon, Ferdinand leNoble, Luc Pardanaud and Christiane Bréant

Int. J. Dev. Biol. (2005) 49: 259-267

Development and pathology of the hyaloid, choroidal and retinal vasculature Magali Saint-Geniez and Patricia A. D'Amore

Int. J. Dev. Biol. (2004) 48: 1045-1058

Parallels in invasion and angiogenesis provide pivotal points for therapeutic intervention

Suzanne A. Eccles

Int. J. Dev. Biol. (2004) 48: 583-598

The stroma reaction myofibroblast: a key player in the control of tumor cell behavior Alexis Desmoulière, Christelle Guyot and Giulio Gabbiani

2006 ISI **Impact Factor $=3.577^{* *}$

Int. J. Dev. Biol. (2004) 48: 509-517

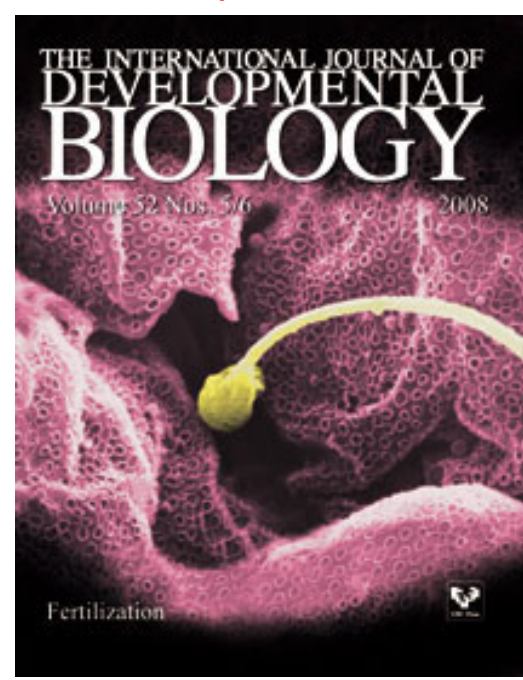

